\title{
Effects of various pre-slaughter conditions on pig carcasses and meat quality in a low-input slaughter facility
}

\author{
N. Čobanović ${ }^{1 \#}$, M. Bošković ${ }^{1}$, D.Vasilev ${ }^{1}$, M. Dimitrijević ${ }^{1}$, N. Parunović ${ }^{2}$, \\ J.Djordjević ${ }^{1}$ \& N. Karabasil ${ }^{1}$ \\ ${ }^{1}$ Faculty of Veterinary Medicine, University of Belgrade, 11000 Belgrade, Serbia \\ ${ }^{2}$ Institute of Meat Hygiene and Technology, Belgrade, 11000 Belgrade, Serbia
}

(Received 4 May 2016; Accepted 13 October 2016; First published online 12 November 2016)

\author{
Copyright resides with the authors in terms of the Creative Commons Attribution 2.5 South African License. \\ See: http://creativecommons.org/licenses/by/2.5/za \\ Condition of use: The user may copy, distribute, transmit and adapt the work, but must recognize the authors and the South African \\ Journal of Animal Science.
}

\begin{abstract}
The aim of this study was to determine the effects of gender, slaughter weight, stocking density, lairage time and season on carcass and meat quality parameters in a low-input production system. The study was conducted on 400 slaughter pigs (200 barrows and 200 gilts) with live weight of $115.0 \pm 4.70 \mathrm{~kg}$. Barrows had higher slaughter and carcass weights, fat thickness and lower meatiness. Heavier pigs had higher hot and cold carcass weights, fat thickness, lower meatiness, and higher incidences of pale, soft and exudative (PSE) and dark, firm and dry (DFD) meat. Low stocking density during transportation increased skin lesion score, $\mathrm{pH}_{45}$ value and the incidence of DFD meat; while high stocking density decreased $\mathrm{pH}_{45}$ value and increased $T_{45}$ value and the incidence of PSE meat. Long lairaging reduced slaughter weight, carcass weight, dressing percentage and backfat thickness and increased skin lesion score. After overnight lairaging, $\mathrm{pH}_{45}$ value and the incidence of DFD meat became higher. After short lairaging, the $\mathrm{pH}_{45}$ value was lower, while the incidence of PSE meat increased. Pigs slaughtered in winter had the highest slaughter weight, backfat thickness, $\mathrm{pH}_{45}$ value and incidence of DFD, and the lowest meatiness. Pigs slaughtered in summer had the lowest slaughter and carcass weights and $\mathrm{pH}_{45}$ value, and the highest incidence of PSE meat. In conclusion, gender influenced carcass quality, slaughter weight and lairage time, and season affected carcass and meat quality, while stocking density had an impact on meat quality.
\end{abstract}

Keywords: DFD meat, gender, lairage time, low-input slaughter system, PSE meat, season, slaughter weight, stocking density

\#Corresponding author: cobanovic.nikola@vet.bg.ac.rs

\section{Introduction}

Appropriate pre-slaughter treatment of pigs is of great importance, from the standpoint of animal welfare and carcass and meat quality (Gajana et al., 2013). The way in which pigs react to pre-slaughter stress depends on factors such as handling during loading and unloading, mixing pigs from different pens, stocking density, time of transportation and lairaging, feed and water deprivation, and the season of slaughter (Dalla Costa et al., 2007, Karabasil et al., 2013a; 2013b). Intense stress immediately prior to slaughter, provoked by inadequate treatment, depletes muscle glycogen, and contributes to rapid glycolysis, with increased lactic acid production early post mortem. Hence, skeletal muscles of acutely stressed pigs show an excessively fast drop in $\mathrm{pH}$ value in the first 60 minutes post mortem, which, in combination with high carcass temperature, results in pale, soft and exudative (PSE) meat (Adzitey \& Nurul, 2011). On the other hand, when pigs are subjected to chronic stress, their muscle glycogen stores are reduced, leading to lower production of lactic acid, and resulting in dark, firm and dry (DFD) meat (Gajana et al., 2013).

It has been reported that stocking density during transportation is a key factor, which can lead to negative effects on animal welfare and meat quality (Pereira et al., 2015), since high- and low-stocking density are both known to increase stress, and have detrimental effects (Guárdia et al., 2004, 2005). The results from earlier studies suggest that lairage time is an important source of variations that determine meat quality (Nanni Costa et al., 2002). After short lairaging $(<1 \mathrm{~h})$, meat was paler, and had a lower $\mathrm{pH}$ value and water-holding capacity, which is typical of PSE meat (Warriss et al., 1998). When pigs were kept in lairage overnight, carcass weight, backfat thickness and meat temperature were reduced, compared with short large time (Warriss et al., 1998). Likewise, the frequency of carcasses with skin lesions and the prevalence of DFD 
meat increased progressively with longer lairage (Warriss et al., 1998). Adverse weather conditions have an impact on ante- and post-mortem muscle glycogen stores, which leads to higher incidences of bruised carcasses and DFD meat in winter, while animal losses and the risk of PSE meat increase in summer (Guárdia et al., 2004, Guárdia et al., 2005, Chulayo \& Muchenje, 2015). Several studies showed that an increase in the slaughter weight of fattening pigs diminishes carcass and meat quality characteristics (Cisneros et al., 1996, Latorre et al., 2004, Czyżak-Runowska et al., 2015). Nonetheless, this view was not supported by all surveys conducted in this area (Correa et al., 2006, Łyczyński et al., 2006). The influence of gender on carcass and meat quality traits has been extensively investigated over the last decades, but the results are not consistent. Some authors did not find any differences in meat quality parameters among barrows and gilts (Alonso et al., 2009, Gispert et al., 2010); while others reported that meat quality was influenced by gender (Bridi et al., 2006, Franco et al., 2008).

Although a number of studies have been conducted to assess and improve carcass and meat quality, most have been carried out in high-input large-scale production systems, which highlights the need to evaluate conditions in low-input production systems. The Republic of Serbia is a relatively small country in south-eastern Europe, with a longstanding tradition of meat production. Of almost 460 establishments that are approved to produce and place meat and meat products on the local market, most are low production systems with local significance. Data on the ways in which pre-slaughter conditions affect carcass and meat quality characteristics in low-input production systems are scarce. This information could assist local farmers and pork producers to better understand the influence of these factors, improve their production systems, and obtain better carcass and pork quality. Therefore, the aim of this study was to determine the effects of gender, slaughter weight, stocking density, lairage time and season of slaughter on carcass and meat quality parameters in a low-input production system.

\section{Materials and methods}

The study was conducted in 2015 on 400 slaughter pigs (200 barrows and 200 gilts), about six months old, with average live weight of $115.0 \pm 4.70 \mathrm{~kg}$. All the animals were of the same breed (Yorkshire $\mathrm{x}$ Landrace crossbreeds) and originated from the same farm. The pigs were fattened in a finishing barn on a fully slatted floor, in groups of 20 animals per pen, with average space allocation of $1 \mathrm{~m}^{2}$ per pig. During the fattening period, the pigs had ad libitum access to food and water. Before transportation, the animals were not subjected to feed and water deprivation. Once loading had been finished from the production site, the pigs were shipped for about 1-2 hours (at a mean speed of $60 \mathrm{~km} / \mathrm{h}$ ) to a single commercial abattoir. Since the information was collected under commercial transport conditions scheduled to pick up animals at several production sites every day, transportation time differed between groups of pigs. The pigs were loaded onto the same commercial transporter by the same driver, and stocking density during transportation ranged from 0.27 to $0.53 \mathrm{~m}^{2} / 100 \mathrm{~kg}$ pig. The animals were monitored through deliveries in 12 consignments (three per season). Depending on the dynamics of slaughter, after unloading, the pigs were held in a lairage less than one hour (on average $44.71 \pm 12.20$ minutes) or more than 20 hours (on average $22.14 \pm 1.57$ hours), when kept overnight and slaughtered the following morning. During lairaging, water was provided, but not food. Stocking density in a lairage pen was $0.65 \mathrm{~m}^{2} / \mathrm{pig}$. The pigs from the same pen were transported and kept in the lairage pens in their social groups, without mixing with other pigs. The animals were not separated by gender during transportation and lairage. The environmental temperature varied in winter from $-1{ }^{\circ} \mathrm{C}$ to $5{ }^{\circ} \mathrm{C}$ (on average $2.25 \pm 2.50^{\circ} \mathrm{C}$ ); in spring from $11^{\circ} \mathrm{C}$ to $17^{\circ} \mathrm{C}$ (on average $14.25 \pm 2.50^{\circ} \mathrm{C}$ ); in summer from 25 ${ }^{\circ} \mathrm{C}$ to $33^{\circ} \mathrm{C}$ (on average $29.00 \pm 3.37^{\circ} \mathrm{C}$ ); and in autumn from $3{ }^{\circ} \mathrm{C}$ to $13^{\circ} \mathrm{C}$ (on average $6.75 \pm 2.25^{\circ} \mathrm{C}$ ). The pigs were slaughtered at the same abattoir, which has a yearly throughput of 13000 pigs and a daily slaughter rate of approximately 35 pigs. Head-only electrical stunning was used with a pair of stunning tongs. In the first 15 seconds after stunning, the pigs were hung by their hind legs for exsanguination. Then the pigs were submerged in the scalding tank for 5 minutes in water heated to between $58.5^{\circ} \mathrm{C}$ and $62{ }^{\circ} \mathrm{C}$. Afterwards, the pigs were placed individually in a dehairer, and remaining hair was removed with a knife and flame. The removal of the viscera from pig carcasses was completed about 45 minutes after slaughter. Pig carcasses were split down the midline, according to standard commercial procedures, and conventionally chilled for 24 hours at $4{ }^{\circ} \mathrm{C}$.

The carcasses (with head, tail, and feet) were weighed immediately after splitting and final washing to obtain the hot carcass weight, and re-weighed 24 hours after chilling to determine the weight of the cooled carcass. The dressing percentage was calculated as (hot carcass weight $\div$ live weight) $\times 100$. A single fat thickness measurement at each of two carcass points (between the 13th and 15th dorsal vertebrae and over M. gluteus medius) was determined in all carcasses using a metal ruler with an accuracy of $1.0 \mathrm{~mm}$. Meatiness (in percentages) was calculated according to Anon (1985), based on hot carcass weight and the sum of carcass fat thickness on the back and at the sacrum. Skin lesions were appraised visually on the left side of the carcasses 45 minutes after slaughter based on the Welfare Quality® protocol (2009). The 
carcasses were divided into the following regions: i) ears; ii) front part of the carcass (from the head to the end of the shoulder); iii) middle part of the carcass (from the end of the shoulder to the rear part of the carcass); iv) rear part of the carcass; and v) limbs (from the accessory digit upwards). Each region of carcass was scored based on a three-point scale: 0 ) no visible skin lesions, or only one skin lesion bigger than $2 \mathrm{~cm}$ or skin blemishes smaller than $1 \mathrm{~cm} ; 1$ ) between two and 10 skin blemishes bigger than $2 \mathrm{~cm}$; and 2) any wound penetrated into muscles or more than 10 skin blemishes larger than $2 \mathrm{~cm}$. The scoring of the five regions of the carcass was combined into one scoring as follows: 0 ) all carcass regions with a score of $0 ; 1$ ) at least one carcass region with a score 1 ; and 2) at least one carcass region with a score 2.

The portable pH-meter Testo 205 (Testo AG, Lenzkirch, Germany) was used to measure meat pH and temperature 45 minutes post mortem on the M. longissimus dorsi, pars lumbalis (central area of the loin), on the left half of the carcass, at the level of the 10th and 11th ribs. Meat quality parameters were both measured in duplicate, and the average of the two measurements was taken as a final result. Carcasses showing $\mathrm{pH}_{45}$ values lower than 6.0 were classified as PSE meat, while carcasses showing $\mathrm{pH}_{45}$ values higher than 6.4 were classified as DFD meat (Adzitey \& Nurul, 2011). The carcasses with $\mathrm{pH}_{45}$ between 6.0 and 6.4 were classified as normal pork quality.

Statistical analysis of the results was conducted with SPSS software version 23.00 for Windows (SPSS, 2015). Based on gender, pigs were allocated to two groups: gilts $(n=200)$; and barrows $(n=200)$. Pigs were divided into two weight groups: pigs with a live weight lower than $115 \mathrm{~kg}$ (lighter pigs) $(\mathrm{n}=200)$; and pigs with a live weight higher than $115 \mathrm{~kg}$ (heavier pigs) $(n=200)$. According to stocking density in the transporter, pigs were classified in three groups: high: $<0.3 \mathrm{~m}^{2} / 100 \mathrm{~kg}$ pig $(\mathrm{n}=154)$; medium: $0.3: 0.5 \mathrm{~m}^{2} / 100$ $\mathrm{kg}$ pig $(\mathrm{n}=118)$; and low: $>0.5 \mathrm{~m}^{2} / 100 \mathrm{~kg}$ pig $(\mathrm{n}=128)$, while animals were divided in two groups for lairage time: short lairaging $(<1 h)(n=229)$; and long lairaging $(>20 h)(n=171)$. Furthermore, according to the season, pigs were classified into four groups. The seasons were classified in this way: December to February was winter $(n=100)$, March to May was spring $(n=100)$, June to August was summer $(n=100)$ and September to November was autumn $(n=100)$. Multivariate analysis of variance (MANOVA) was performed to test the effects of gender, slaughter weight, stocking density in the transporter, lairage time and season, and all possible interactions on the carcass and meat quality parameters. All 2-, 3-, 4- and 5-way interactions were tested and removed from model if $P>0.05$. Interactions were not significant $(P>0.05)$ (data not shown). Therefore, data were pooled across treatments and reported in the tables and discussed in the text according to the main effects of each factor. Data were described by descriptive statistical parameters as the mean value and standard error of the mean. Also, Pearson correlation analysis was run between the slaughter weight, stocking density, lairage time and seasonal temperature and carcass and meat quality parameters to numerically summarise the degree of association between any two variables. The incidence of meat quality classes in relation to the gender, slaughter weight and lairaging was determined by Fisher's exact test. Chi-square test was used to determine the incidence of meat quality classes with respect to the stocking density in the transporter and to the season of slaughter. The individual pig was considered an experimental unit for all statistical analyses. In all cases, values of $P<0.05$ were considered significant.

\section{Results and Discussion}

The effect of gender on the carcass and meat quality parameters and the incidence of meat quality classes can be seen in Table 1. Slaughter weight and hot and cold carcass weights differ $(P<0.05)$ between genders, which is consistent with the findings of Latorre et al. (2004) and Gispert et al. (2010). Fat thicknesses on the back and at the sacrum were both higher $(P<0.05)$ in barrows compared with gilts. This was also observed in the studies of Latorre et al. (2003), Jaturasitha et al. (2006) and Oliveira et al. (2015). In addition, barrows had lower meatiness than gilts $(P<0.05)$, which is in concordance with the results of Latorre et al. (2008) and Oliveira et al. (2015). It is known that testosterone promotes muscle growth, but, when lacking, as in barrows, energy is transferred to fat tissue at a higher rate, which significantly affects the meat/fat ratio (Jaturasitha et al., 2006). Furthermore, the $\mathrm{pH}_{45}$ and $\mathrm{T}_{45}$ values and incidence of PSE and DFD meat did not differ between genders $(P>0.05)$, as depicted in Table 1. Analogous observations were reported in the studies of Alonso et al. (2009) and Gispert et al. (2010). Pre-slaughter conditions, imposed during transportation and lairaging at the abattoir, are important factors that influence the $\mathrm{pH}$ value of meat, and therefore various stressors might affect gilts and castrated male pigs differently (Pineiro et al., 2001).

The effect of slaughter weight on the carcass and meat quality parameters and the incidence of meat quality classes are reported in Table 1. From this table, it is evident that heavier pigs had higher hot and cold carcass weights, fat thickness at two points, a lower percentage of meat in comparison with lighter pigs $(P<0.05)$. It has been reported that hot and cold carcass weights increased by 0.81 and $0.79 \mathrm{~kg}$, respectively, per $\mathrm{kg}$ increase in body weight (Cisneros et al., 1996). Latorre et al. (2004) reported a linear increase in fat thickness of $2.4 \mathrm{~mm}$ on the back and $2.3 \mathrm{~mm}$ over M. gluteus medius per each $10 \mathrm{~kg}$ increase in slaughter weight over $116 \mathrm{~kg}$. Moreover, Hugo \& Roodt (2015) found that lighter pigs had significantly 
higher lean meat content compared with heavier pigs. These results are supported because in this investigation the increase in slaughter weight resulted in increased hot carcass weight $(r=0.91, P<0.05)$, cold carcass weight $(r=0.90, P<0.05)$, fat thickness on the back $(r=0.37, P<0.05)$ and sacrum $(r=0.36, P$ $<0.05)$, but decreased meatiness $(r=-0.38, P<0.05)$ (Table 4). In accordance with the findings of Guàrdia et al. (2009), heavier pigs had higher skin lesion scores than lighter pigs $(P<0.05)$ (Table 1$)$. It has been found that the largest pigs in a herd fight more and have greater probability of winning a fight (Guàrdia et al., 2009). Hence, pre-slaughter handling with heavy pigs should be practised with care. Several studies reported a positive dependence between slaughter weight, aggressive behaviour and skin lesions on the carcass (Olessen et al., 1996, Turner et al., 2006). Although the correlation coefficient between slaughter weight and skin lesion score was weak $(r=0.12, P<0.05)$ (Table 4), it suggests that the risk of obtaining skin blemishes on carcasses was slightly higher in heavier pigs. As seen in Table 1, the incidences of PSE and DFD meat differ between lighter and heavier pigs $(P<0.05)$. Many authors state that an increase in slaughter weight from $116 \mathrm{~kg}$ to $133 \mathrm{~kg}$ did not influence meat quality positively (Latorre et al., 2004). Czyżak-Runowska et al. (2015) point out that heavier pigs produced lower meat quality three times more often than pigs with a lower body mass.

Table 1 Effects of gender and slaughter weight on carcass and meat quality parameters (mean value and standard error of the mean) and incidence of meat quality classes $(n=400)$

\begin{tabular}{|c|c|c|c|c|c|c|}
\hline & \multicolumn{2}{|c|}{ Gender } & \multicolumn{4}{|c|}{ Slaughter weight } \\
\hline & $\begin{array}{c}\text { Gilts } \\
(n=200)\end{array}$ & $\begin{array}{l}\text { Barrows } \\
(n=200)\end{array}$ & Significance & $\begin{array}{l}\text { Lighter pigs } \\
(\mathrm{n}=200)\end{array}$ & $\begin{array}{l}\text { Heavier pigs } \\
(n=200)\end{array}$ & Significance \\
\hline \multicolumn{7}{|c|}{ Carcass quality } \\
\hline SW (kg) & $112.2^{\mathrm{a}} \pm 0.27$ & $117.9^{b} \pm 0.25$ & * & $111.4^{\mathrm{a}} \pm 0.23$ & $118.6^{b} \pm 0.20$ & * \\
\hline $\mathrm{HCW}(\mathrm{kg})$ & $91.75^{a} \pm 0.31$ & $96.12^{b} \pm 0.26$ & * & $91.06^{a} \pm 0.28$ & $96.81^{b} \pm 0.23$ & * \\
\hline CCW (kg) & $88.53^{a} \pm 0.31$ & $93.38^{b} \pm 0.28$ & * & $87.78^{\mathrm{a}} \pm 0.27$ & $94.13^{b} \pm 0.24$ & * \\
\hline DP (\%) & $81.77 \pm 0.12$ & $81.52 \pm 0.12$ & NS & $81.68 \pm 0.12$ & $81.61 \pm 0.12$ & NS \\
\hline FTB $(\mathrm{mm})$ & $15.04^{a} \pm 0.43$ & $19.55^{b} \pm 0.66$ & * & $14.17^{\mathrm{a}} \pm 0.32$ & $20.42^{b} \pm 0.69$ & * \\
\hline FTS (mm) & $26.28^{a} \pm 0.76$ & $34.71^{b} \pm 1.36$ & * & $24.73^{\mathrm{a}} \pm 0.64$ & $36.26^{b} \pm 1.36$ & * \\
\hline $\mathrm{M}(\%)$ & $42.97^{a} \pm 0.24$ & $40.38^{b} \pm 0.37$ & * & $43.47^{a} \pm 0.19$ & $39.89^{b} \pm 0.38$ & * \\
\hline SLC & $1.10 \pm 0.06$ & $1.10 \pm 0.05$ & NS & $0.98^{\mathrm{a}} \pm 0.06$ & $1.18^{b} \pm 0.05$ & * \\
\hline \multicolumn{7}{|l|}{ Meat quality } \\
\hline $\mathrm{pH}_{45}$ & $6.20 \pm 0.02$ & $6.23 \pm 0.01$ & NS & $6.19 \pm 0.02$ & $6.23 \pm 0.01$ & NS \\
\hline $\mathrm{T}_{45}\left({ }^{\circ} \mathrm{C}\right)$ & $39.39 \pm 0.08$ & $39.26 \pm 0.08$ & NS & $39.39 \pm 0.07$ & $39.26 \pm 0.08$ & NS \\
\hline \multicolumn{7}{|c|}{ Meat quality classes } \\
\hline PSE (\%) & 12.00 & 12.50 & NS & $8.50^{a}$ & $16.00^{\mathrm{b}}$ & * \\
\hline Normal (\%) & 65.00 & 64.00 & NS & $73.50^{\mathrm{a}}$ & $55.50^{\mathrm{b}}$ & * \\
\hline DFD (\%) & 23.00 & 23.50 & NS & $18.00^{\mathrm{a}}$ & $28.50^{\mathrm{b}}$ & * \\
\hline
\end{tabular}

Lighter pigs: pigs with live weight lower than $115 \mathrm{~kg}$; heavier pigs: pigs with a live weight higher than $115 \mathrm{~kg}$

SW: slaughter weight; HCW: hot carcass weight; CCW: cold carcass weight; DP: dressing percentage; FTB: fat carcass thickness on the back; FTS: fat carcass thickness at the sacrum; M: meatiness; SLC: skin lesion score; $\mathrm{pH}_{45}$ : $\mathrm{meat}_{\mathrm{pH}}$ values measured 45 minutes post mortem; $\mathrm{T}_{45}$ : meat temperature measured 45 minutes post mortem

DFD meat: $\mathrm{pH}_{45}>6.4$; normal meat: $\mathrm{pH}_{45}$ between 6.0 and 6.4: PSE meat: $\mathrm{pH}_{45}<6$

* Statistical significance at $(P<0.05)$; NS: not significant $(P>0.05)$

- Different letters in the same row indicate a significant difference at $P<0.05\left({ }^{\mathrm{a}-\mathrm{b}}\right)$

The effect of stocking density on the carcass and meat quality parameters and the incidence of meat quality classes are shown in Table 2. There were no differences between stocking densities for most carcass quality traits, including slaughter weight, hot and cold carcass weights, backfat thickness at two points, and meatiness $(P>0.05)$. Similar results were reported by Guise et al. (1998) and Nanni Costa et al. (2002), who did not find evidence that transport stocking density had an impact on the carcass quality parameters. 
In the present study, the group of pigs transported at low stocking density had the highest skin lesion score, $\mathrm{pH}_{45}$ value and incidence of DFD meat $(P<0.05)$. As a consequence of excessive space allowance, standing posture during transportation may result in pigs losing their balance when the transporter negotiates bends and poor road surfaces or they can be thrown around and be struck. This practice can result in higher skin lesion score because of trampling and falls (Barton-Gade \& Christensen, 1998). In addition, pigs transported at low stocking density can move around, which leads to confrontations and fights (Guàrdia et al., 2005). Consequently, aggressive behaviour can cause muscular fatigue and breakdown of muscle glycogen stores, which increase the tendency towards DFD meat (Guàrdia et al., 2005). This tendency was confirmed in the present study, where the decrease in stocking density in the transporter increased $\mathrm{pH}_{45}$ value $(r=-0.64, P<0.05)$ (Table 4). Conversely, the group of pigs transported at high stocking density had the lowest $\mathrm{pH}_{45}$ value, highest $\mathrm{T}_{45}$ value, and incidence of PSE meat $(P<0.05)$ (Table 2). A negative effect of overstocking during transportation could be connected to the lack of resting space, which leads pigs to fight, resulting in a higher prevalence of skin lesions (Guàrdia et al., 2009). These behavioural alterations affect the muscle metabolic rate immediately after slaughter, leading to breakdown of the glycogen stores owing to the increased requirement of adenosine triphosphate, and accelerate the rate of $\mathrm{pH}$ fall by the formation of lactic acid in skeletal muscle, which contributes to the increased incidence of PSE meat (Pereira et al., 2015). This was confirmed in the present research, where, overcrowding the pigs by reducing their space allocation in the transporter decreased the $\mathrm{pH}_{45}$ value $(r=-0.43, P<0.05)$ and increased the $\mathrm{T}_{45}$ value of meat $(r=0.30, P<0.05)$ (Table 4). The findings of this study showed the negative effect of high $\left(<0.3 \mathrm{~m}^{2} / 100\right.$ $\mathrm{kg}$ pig) and low $\left(>0.5 \mathrm{~m}^{2} / 100 \mathrm{~kg}\right)$ stocking density on skin lesion score, $\mathrm{pH}_{45}$ and $\mathrm{T}_{45}$ values, and on the incidence of PSE and DFD meat. It may be argued that excessive and insufficient space availability both compromised pig welfare and caused a deterioration in pork quality. Accordingly, when pigs were transported at medium stocking density (between $0.3 \mathrm{~m}^{2} / 100 \mathrm{~kg}$ pig and $0.5 \mathrm{~m}^{2} / 100 \mathrm{~kg}$ ), the results showed much lower risks of obtaining inferior pork quality $(P<0.05$, Table 2). At this point, consensus has not been reached for recommendations of stocking density during transportation for slaughter pigs (Pereira et al., 2015). According to the National Pork Board (2008), the recommended stocking density in the United States is around $0.33 \mathrm{~m}^{2} / \mathrm{pig}$. Guàrdia et al. (2004) emphasise that each pig must be able to stand or lie down in its natural position. As recommended by the European Union (EU) regulations, this could be achieved with a space allowance of around $235 \mathrm{~kg} / \mathrm{m}^{2}$ or $0.425 \mathrm{~m}^{2}$ per $100 \mathrm{~kg}$ pig, which would have a beneficial effect on animal wellbeing, pork quality and transport economy (European Commission, 2005). However, EU regulations allow farmers and pork producers to adjust the stocking density based on climatic conditions, transportation time, body weight, physical condition, and genetics of the slaughter pigs (European Commission, 2005).

The effect of lairage time on the carcass and meat quality parameters and the incidence of meat quality classes is displayed in Table 2. After long lairaging, the group of pigs showed lower slaughter weight, hot and cold carcass weights, dressing percentage, and fat thickness on the back, and higher skin lesion scores compared with short lairaging $(P<0.05)$. These results were strengthened because in the present research, slaughter weight $(r=-0.18, P<0.05)$, hot carcass weight $(r=-0.24, P<0.05)$, cold carcass weight $(r=-0.24, P<0.05)$ and dressing percentage $(r=-0.24, P<0.05)$ were reduced by increasing lairage time (Table 4). Furthermore, overnight lairaging reduced backfat thickness $(r=-0.11, P<0.05)$ and increased skin lesion score $(r=0.12, P<0.05)$ (Table 4). The major reasons for losses in slaughter and carcass weight during lairaging are certainly the reduction of the gastrointestinal tract and bladder content induced by feed and water deprivation, as well as water loss, and the depletion of muscle glycogen stores for obtaining energy (Lambertini et al., 2006, Adzitey, 2011). As stated by Dalla Costa et al. (2016), fasting time of $24 \mathrm{~h}$ prior to slaughter resulted in a reduction of slaughter weight and dressing percentage, in terms of $100 \mathrm{~g}$ weight loss per hour. It seems that the combined effect of feed and water deprivation and prolonged lairaging increased slaughter and carcass weight loss (Lambertini et al., 2006).

In this study, the group of pigs that were subjected to long lairaging had higher $\mathrm{pH}_{45}$ value and incidence of DFD meat $(P<0.05)$ (Table 2). In fact, long lairaging reduces the incidence of PSE meat, and allows the pigs to rest, but increases the $\mathrm{pH}$ value and the proportion of DFD meat. The increase in the $\mathrm{pH}$ value after overnight lairaging is a consequence of muscle glycogen depletion caused by the combined effects of feed deprivation and physical activity associated with aggression and fighting among pigs (Faucitano, 2010). Indeed, extended lairaging (overnight to $>24 \mathrm{~h}$ ) increases fighting rate and thus the skin lesion score (Faucitano, 2010). Guàrdia et al. (2009) reported a twice-higher risk of skin lesions in pigs kept in lairage for $15 \mathrm{~h}$ compared with $3 \mathrm{~h}(18 \%$ vs. $10 \%)$. 


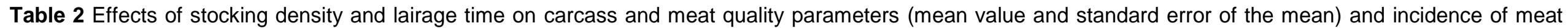
quality classes $(n=400)$

\begin{tabular}{|c|c|c|c|c|c|c|c|}
\hline & \multicolumn{3}{|c|}{ Stocking density } & \multicolumn{4}{|c|}{ Lairage time } \\
\hline & $\begin{array}{c}\text { High } \\
(n=154)\end{array}$ & $\begin{array}{l}\text { Medium } \\
(\mathrm{n}=118)\end{array}$ & $\begin{array}{c}\text { Low } \\
(n=128)\end{array}$ & Significance & $\begin{array}{c}\text { Short } \\
(n=229)\end{array}$ & $\begin{array}{c}\text { Long } \\
(\mathrm{n}=171)\end{array}$ & Significance \\
\hline \multicolumn{8}{|c|}{ Carcass quality } \\
\hline SW (kg) & $115.3 \pm 0.37$ & $114.9 \pm 0.46$ & $114.9 \pm 0.41$ & NS & $115.7^{a} \pm 0.29$ & $114.1^{\mathrm{b}} \pm 0.37$ & * \\
\hline HCW (kg) & $94.33 \pm 0.34$ & $93.98 \pm 0.48$ & $93.41 \pm 0.39$ & NS & $94.90^{a} \pm 0.28$ & $92.65^{b} \pm 0.36$ & * \\
\hline CCW (kg) & $91.24 \pm 0.38$ & $90.98 \pm 0.49$ & $90.59 \pm 0.40$ & NS & $91.94^{\mathrm{a}} \pm 0.30$ & $89.64^{b} \pm 0.38$ & * \\
\hline DP (\%) & $81.81^{a} \pm 0.12$ & $81.79 \pm 0.18$ & $81.31^{b} \pm 0.13$ & * & $81.99^{a} \pm 0.11$ & $81.19^{b} \pm 0.12$ & * \\
\hline FTB (mm) & $17.49 \pm 0.63$ & $16.37 \pm 0.74$ & $17.90 \pm 0.76$ & NS & $18.06^{\mathrm{a}} \pm 0.57$ & $16.26^{b} \pm 0.57$ & * \\
\hline FTS (mm) & $30.39 \pm 1.31$ & $30.67 \pm 1.54$ & $30.46 \pm 1.37$ & NS & $31.12 \pm 1.01$ & $29.65 \pm 1.30$ & NS \\
\hline M (\%) & $41.61 \pm 0.37$ & $41.86 \pm 0.44$ & $41.59 \pm 0.40$ & NS & $41.41 \pm 0.30$ & $42.04 \pm 0.35$ & NS \\
\hline SLC & $1.08^{\mathrm{ab}} \pm 0.06$ & $0.58^{\mathrm{ac}} \pm 0.06$ & $1.54^{b c} \pm 0.06$ & * & $0.99^{a} \pm 0.05$ & $1.19^{b} \pm 0.06$ & * \\
\hline \multicolumn{8}{|l|}{ Meat quality } \\
\hline $\mathrm{pH}_{45}$ & $6.10^{\mathrm{ab}} \pm 0.02$ & $6.21^{\mathrm{ac}} \pm 0.01$ & $6.34^{b c} \pm 0.02$ & * & $6.16^{a} \pm 0.01$ & $6.27^{b} \pm 0.02$ & * \\
\hline $\mathrm{T}_{45}\left({ }^{\circ} \mathrm{C}\right)$ & $39.72^{\mathrm{ab}} \pm 0.09$ & $39.15^{a} \pm 0.07$ & $39.00^{b} \pm 0.11$ & * & $39.39 \pm 0.07$ & $39.22 \pm 0.01$ & NS \\
\hline \multicolumn{8}{|c|}{ Meat quality classes } \\
\hline PSE (\%) & $26.62^{a b}$ & $2.54^{\mathrm{a}}$ & $3.91^{b}$ & * & $16.59^{\mathrm{a}}$ & $6.43^{b}$ & * \\
\hline Normal (\%) & $55.20^{\mathrm{a}}$ & $94.07^{\mathrm{ab}}$ & $48.43^{b}$ & * & 66.81 & 61.41 & NS \\
\hline DFD (\%) & $18.18^{\mathrm{ab}}$ & $3.39^{\mathrm{ac}}$ & $47.66^{b c}$ & * & $16.59^{a}$ & $32.16^{\mathrm{b}}$ & * \\
\hline
\end{tabular}

Stocking density: high: $<0.3 \mathrm{~m}^{2} / 100 \mathrm{~kg}$ pig; medium: 0.3-0.5 m²/100 kg pig; low: $>0.5 \mathrm{~m}^{2} / 100 \mathrm{~kg}$ pig. Lairage time: short $<1 \mathrm{~h}$; long $>20 \mathrm{~h}$.

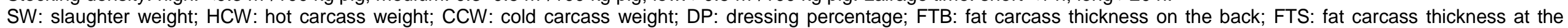
sacrum; M: meatiness; SLC: skin lesion score; $\mathrm{pH}_{45}$ : meat $\mathrm{pH}$ values measured 45 minutes post mortem; $\mathrm{T}_{45}$ : meat temperature measured 45 minutes post mortem.

DFD meat: $\mathrm{pH}_{45}>6.4$; normal meat: $\mathrm{pH}_{45}$ between 6.0 and 6.4: PSE meat: $\mathrm{pH}_{45}<6$

* Statistical significance at $(P<0.05)$; NS: not significant $(P>0.05)$

- Different letters in the same row indicate a significant difference at $P<0.05\left({ }^{a-c}\right)$ 
In spite of relatively low $r$-values (Table 4) determined between lairage time and $\mathrm{pH}_{45}$ value $(\mathrm{r}=0.24, P$ $<0.05)$ and skin lesion score $(r=0.12, P<0.05)$, pigs subjected to long lairaging were presumably under chronic stress and therefore produced lower meat quality. However, the opposite trend was detected as a response to acute stressors, where, after short lairaging $(<1 \mathrm{~h})$, the $\mathrm{pH}_{45}$ value became lower $(P<0.05)$ and the incidence of PSE meat was higher $(P<0.05)$ (Table 2). On the day of slaughter, the most stressful procedures are transportation and lairaging, probably because of the combined impacts of handling, change of the environment, and mixing with pigs from different pens (Grandin, 2003). Pigs that underwent short lairaging would not have sufficient time to recuperate from these initial stressors (Pérez et al., 2002). Therefore, the slaughter of pigs without rest or after short lairaging (15-60 minutes) is not recommended, because animals are exhausted and agitated (Vermeulen et al., 2015). The oxygen demand for aerobic glycogen depletion in acutely stressed pigs cannot be satisfied due to the decrease in blood supply to muscles, which contributes to higher production of lactic acid through the anaerobic metabolic pathway and elevates muscle temperature $\left(+1^{\circ} \mathrm{C}\right)$, consequently increasing the occurrence of PSE meat (Choe et al., 2015). The primary purpose of lairage is to help animals to recover from transport-associated stress, and it is expected to improve meat quality (Guàrdia et al., 2009). The results from earlier studies suggest that 2-4 hours is an appropriate lairage time to reduce pre-slaughter stress and obtain better carcass and meat quality (Perez et al., 2002, Zhen et al., 2013). Nonetheless, lairage time should be adjusted according to the transportation time; otherwise, excessively short or long lairage time could induce acute or chronic stress, and this might compromise animal wellbeing and subsequently the properties of pork (Jama et al., 2016).

The effect of season on the carcass and meat quality parameters, and the incidence of meat quality classes are provided in Table 3.

Table 3 Effect of season on the carcass and meat quality parameters (mean value and standard error of the mean) and the incidence of meat quality classes $(n=400)$

\begin{tabular}{|c|c|c|c|c|c|}
\hline \multicolumn{6}{|c|}{ Season } \\
\hline & $\begin{array}{l}\text { Autumn } \\
(\mathrm{n}=100)\end{array}$ & $\begin{array}{c}\text { Winter } \\
(\mathrm{n}=100)\end{array}$ & $\begin{array}{c}\text { Spring } \\
(n=100)\end{array}$ & $\begin{array}{c}\text { Summer } \\
(n=100)\end{array}$ & Significance \\
\hline \multicolumn{6}{|c|}{ Carcass quality } \\
\hline SW (kg) & $115.4^{\mathrm{ab}} \pm 0.43$ & $117.2^{\mathrm{acd}} \pm 0.41$ & $114.7^{\mathrm{ce}} \pm 0.44$ & $112.8^{\text {bde }} \pm 0.49$ & * \\
\hline $\mathrm{HCW}(\mathrm{kg})$ & $94.13^{a} \pm 0.40$ & $95.13^{b} \pm 0.41$ & $94.31^{\mathrm{abc}} \pm 0.46$ & $92.17^{c} \pm 0.51$ & * \\
\hline $\mathrm{CCW}(\mathrm{kg})$ & $91.20^{\mathrm{a}} \pm 0.40$ & $92.64^{b} \pm 0.42$ & $90.99^{c} \pm 0.51$ & $88.99^{\mathrm{abc}} \pm 0.52$ & * \\
\hline DP (\%) & $81.57^{a} \pm 0.15$ & $81.13^{b} \pm 0.15$ & $82.18^{a b} \pm 0.18$ & $81.70 \pm 0.17$ & * \\
\hline FTB (mm) & $15.71^{\mathrm{a}} \pm 0.78$ & $21.58^{\mathrm{abc}} \pm 0.98$ & $16.47^{b} \pm 0.72$ & $15.40^{c} \pm 0.58$ & * \\
\hline FTS (mm) & $26.70^{\mathrm{a}} \pm 1.20$ & $38.04^{\mathrm{abc}} \pm 1.88$ & $29.45^{\mathrm{b}} \pm 1.65$ & $27.79^{\mathrm{C}} \pm 1.40$ & * \\
\hline $\mathrm{M}(\%)$ & $42.73^{\mathrm{a}} \pm 0.38$ & $39.35^{\mathrm{abc}} \pm 0.53$ & $42.05^{\mathrm{b}} \pm 0.45$ & $42.57^{\mathrm{C}} \pm 0.39$ & * \\
\hline SLC & $1.00^{a} \pm 0.08$ & $1.46^{\mathrm{abc}} \pm 0.06$ & $0.95^{b} \pm 0.07$ & $0.89^{c} \pm 0.08$ & * \\
\hline \multicolumn{6}{|l|}{ Meat quality } \\
\hline $\mathrm{pH}_{45}$ & $6.29^{\mathrm{abc}} \pm 0.02$ & $6.41^{\text {ade }} \pm 0.01$ & $6.11^{\mathrm{bdf}} \pm 0.02$ & $6.03^{\mathrm{cef}} \pm 0.02$ & * \\
\hline $\mathrm{T}_{45}\left({ }^{\circ} \mathrm{C}\right)$ & $39.05^{\mathrm{ab}} \pm 0.08$ & $38.87^{\mathrm{cd}} \pm 0.13$ & $39.69^{\mathrm{ac}} \pm 0.09$ & $39.67^{\mathrm{bd}} \pm 0.11$ & * \\
\hline \multicolumn{6}{|c|}{ Meat quality classes } \\
\hline PSE (\%) & $3.00^{\mathrm{ab}}$ & $2.00^{\mathrm{cd}}$ & $10.00^{\text {ace }}$ & $34.00^{\text {bde }}$ & * \\
\hline Normal (\%) & $68.00^{\mathrm{ab}}$ & $45.00^{\mathrm{acd}}$ & $83.00^{\text {bce }}$ & $62.00^{\mathrm{de}}$ & * \\
\hline DFD (\%) & $29.00^{\mathrm{abc}}$ & $53.00^{\text {ade }}$ & $7.00^{\mathrm{bd}}$ & $4.00^{\mathrm{ce}}$ & * \\
\hline \multicolumn{6}{|c|}{$\begin{array}{l}\text { SW: slaughter weight; HCW: hot carcass weight; CCW: cold carcass weight; DP: dressing percentage; FTB: fat carcass } \\
\text { thickness on the back; FTS: fat carcass thickness at the sacrum; M: meatiness; SLC: skin lesion score; } \mathrm{pH} 45: \mathrm{meat}_{45} \mathrm{pH} \\
\text { values measured } 45 \text { minutes post mortem; } \mathrm{T}_{45} \text { : Meat temperature measured } 45 \text { minutes post mortem } \\
\text { DFD meat: } \mathrm{pH}_{45}>6.4 \text {; normal meat: } \mathrm{pH}_{45} \text { between } 6.0 \text { and } 6.4: \mathrm{PSE} \text { meat: } \mathrm{pH}_{45}<6 \\
\text { * Statistical significance at }(P<0.05) ; \mathrm{NS} \text { : not significant }(P>0.05) \\
\text { - Different letters in the same row indicate a significant difference at } P<0.05\left({ }^{\mathrm{a}-\mathrm{d}}\right)\end{array}$} \\
\hline
\end{tabular}


With respect to season, the pigs slaughtered in winter had the highest slaughter weight and backfat thickness at two points, and lowest meatiness $(P<0.05)$. Conversely, the pigs slaughtered in summer had the lowest slaughter weight, lowest hot carcass weight, and lowest cold carcass weight $(P<0.05)$. Indeed, a negative association between seasonal temperature and slaughter weight $(r=-0.33, P<0.05)$, hot carcass weight $(r=-0.23, P<0.05)$ and cold carcass weight $(r=-0.26, P<0.05)$ was found in the current study (Table 4), which concur with the results of Piwczyński et al. (2013). This could be because pigs fattened in winter consumed more feed and had higher live weight and thicker backfat, compared with those fattened in summer (Hale, 1971), since low environmental temperatures increase the appetite as a reflection of increased metabolic demands (Goumon et al., 2013). Moreover, the pigs reared in summer consumed 3\% less feed per day, and grew on average 5\% more slowly than pigs reared in winter (Myer \& Bucklin, 2007). As shown in Table 3, the pigs slaughtered in winter had the highest skin lesion score, $\mathrm{pH}_{45}$ value, and incidence of DFD meat $(P<0.05)$. Over winter, the most important causes for a higher proportion of carcasses with skin lesions are falls and slips at unloading (Correa et al., 2013) and in particular during transportation (Scheeren et al., 2014). In addition, a higher proportion of heavier pigs were slaughtered in winter. They needed more force to load, which resulted in a higher frequency of animals hitting the loading alley and ramp walls, which led to more human-inflicted types of skin lesions (Correa et al., 2013). The recommended thermo-neutral zone for slaughter pigs is from $15{ }^{\circ} \mathrm{C}$ to $25^{\circ} \mathrm{C}$ (Dalla Costa et al., 2007). In summer and winter transportation, the ambient temperature often exceeds or falls below the threshold for heat and cold stress, which could adversely affect animal wellbeing, carcass and pork quality (Guàrdia et al., 2005, Gosálvez et al., 2006, Dalla Costa et al., 2007). When ambient temperature falls below the lower threshold of thermal tolerance, pigs tend to maintain body temperature by huddling to create a warmer microclimate, which protects them from cold (Dalla Costa et al., 2007). However, grouping pigs decreases the space allocation, which increases fights and attempts to find a place to rest, leading to increased skin lesion scores (Gosálvez et al., 2006). When the pig fails to maintain heat balance, shivering increases heat production; accelerating the breakdown of muscle glycogen stores and limiting $\mathrm{pH}$ decline post mortem, which increases the likelihood of DFD meat (Gosálvez et al., 2006). In the current study, the decrease in ambient temperature resulted in increased $\mathrm{pH}_{45}$ value $(\mathrm{r}=-0.64, P<0.05)$ and skin lesion scores $(\mathrm{r}=-0.22, P$ $<0.05$ ) (Table 4), which confirmed that the risk of skin damage on carcasses and DFD meat was higher in pigs slaughtered in colder months. Therefore, animals might benefit from additional insulation with appropriate bedding in the transporter and holding pens, which would protect them from cold stress, and ensure thermal comfort (Goumon et al., 2013). In the present research, the pigs slaughtered in summer had the lowest $\mathrm{pH}_{45}$ value and the highest incidence of PSE meat $(P<0.05)$ (Table 3), as observed by other researchers (Guàrdia et al., 2004, Correa et al., 2013, Čobanović et al., 2016). Because pigs do not have functional sweat glands, they have limited capacity to dissipate body heat rapidly enough and are sensitive to warm ambient conditions (Guàrdia et al., 2004). Hence, when the environmental temperature reaches the upper threshold for heat stress, muscle temperature is likely to rise, speeding up the breathing rate, and accelerating metabolism, thus increasing a tendency to PSE meat (Guàrdia et al., 2004, Fox et al., 2014). This tendency was confirmed in the current study, where the increase in seasonal temperature reduced $\mathrm{pH}_{45}$ value $(r=-0.64, P<0.05)$ and elevated $\mathrm{T}_{45}$ value $(r=0.29, P<0.05)$ (Table 4$)$. In summer, it is recommended that negative effects of heat stress should be alleviated with appropriate transport practices and showering during lairaging (Nanonni et al., 2014). Pre-slaughter showering of pigs leads to a reduction of body temperature by $10 \%\left(3-4^{\circ} \mathrm{C}\right)$, has a beneficial impact on $\mathrm{pH}$ value, and could improve pork quality (Nanonni et al., 2014).

Table 4 Correlations between slaughter weight, stocking density, lairage time and seasonal temperature and carcass and meat quality parameters

\begin{tabular}{|c|c|c|c|c|c|c|c|c|c|c|}
\hline Parameters & $\begin{array}{l}\text { SW } \\
(\mathrm{kg})\end{array}$ & $\begin{array}{l}\begin{array}{l}\text { HCW } \\
(\mathbf{k g})\end{array} \\
\end{array}$ & $\begin{array}{l}\begin{array}{l}\text { CCW } \\
(\mathrm{kg})\end{array} \\
\end{array}$ & $\begin{array}{l}\text { DP } \\
(\%)\end{array}$ & $\begin{array}{l}\begin{array}{l}\text { FTB } \\
(\mathrm{mm})\end{array} \\
\end{array}$ & $\begin{array}{l}\begin{array}{l}\text { FTS } \\
(\mathrm{mm})\end{array} \\
\end{array}$ & $\begin{array}{l}\mathbf{M} \\
(\%)\end{array}$ & SLC & $\mathrm{pH}_{45}$ & $\begin{array}{l}\mathrm{T}_{45} \\
\left({ }^{\circ} \mathrm{C}\right)\end{array}$ \\
\hline $\begin{array}{l}\text { Slaughter weight } \\
\text { Stocking density } \\
\text { Lairage time }\end{array}$ & $\begin{array}{l}1 \\
0.04 \\
-0.18^{*}\end{array}$ & $\begin{array}{l}0.91^{*} \\
0.08 \\
-0.24^{*}\end{array}$ & $\begin{array}{l}0.90^{*} \\
0.05 \\
-0.24^{*}\end{array}$ & $\begin{array}{l}0.20^{*} \\
0.10^{*} \\
-0.24^{*}\end{array}$ & $\begin{array}{l}0.37^{*} \\
0.01 \\
-0.11^{*}\end{array}$ & $\begin{array}{l}0.36^{*} \\
-0.004 \\
-0.05\end{array}$ & $\begin{array}{l}-0.38^{*} \\
-0.01 \\
0.07\end{array}$ & $\begin{array}{l}0.12^{*} \\
-0.08 \\
0.12^{*}\end{array}$ & $\begin{array}{l}0.08 \\
-0.43^{*} \\
0.24^{*}\end{array}$ & $\begin{array}{l}-0.07 \\
0.30^{*} \\
-0.08\end{array}$ \\
\hline $\begin{array}{l}\text { Seasonal } \\
\text { temperature }\end{array}$ & $-0.33^{*}$ & $-0.23^{*}$ & $-0.26^{*}$ & $0.11^{*}$ & $-0.20^{*}$ & $-0.16^{*}$ & $0.18^{*}$ & $-0.22^{*}$ & $-0.64^{*}$ & $0.29^{*}$ \\
\hline
\end{tabular}

SW: slaughter weight; HCW: hot carcass weight; CCW: cold carcass weight; DP: dressing percentage; FTB: fat carcass thickness on the back; FTS: fat carcass thickness at the sacrum; M: meatiness; SLC: skin lesion score; $\mathrm{pH}_{45}: \mathrm{meat}_{\mathrm{pH}}$ values measured 45 minutes post mortem; $T_{45}$ : meat temperature measured 45 minutes post mortem

* Statistical significance at $(\mathrm{P}<0.05)$. 


\section{Conclusion}

The results showed that gender differences were associated mainly with carcass quality parameters, showing gilts to be superior (higher meatiness and less fat) to barrows. In contrast, gender did not affect meat quality. Heavier pigs were fatter, and had a lower percentage of meat than lighter pigs. The increase in slaughter weight caused a significant deterioration in meat quality. The risk of obtaining lower meat quality was almost twofold higher in heavier pigs. These findings suggest that fattening pigs at a live weight above $115 \mathrm{~kg}$ does not have a beneficial effect on carcass and meat quality. The impact of stocking density on carcass quality was negligible, while the effects on animal welfare and meat quality were substantial. The pigs transported at inadequate stocking density displayed a higher number of skin lesions on the carcass and had a higher tendency towards PSE and DFD meat. It can therefore be concluded that from the aspect of animal welfare and meat quality, medium stocking density is the best compromise to obtain optimal carcass and pork quality. A short or excessively long lairage period compromises animal welfare and reduced carcass and meat quality. From the standpoint of animal welfare and carcass and meat quality, it is recommended that slaughter pigs should be rested for two to four hours before slaughter. The pigs slaughtered in winter were heavier and fatter and had less carcass meat than those slaughtered in all other seasons. Therefore, the lowest carcass quality was in the pigs slaughtered in winter. Besides, low and high environmental temperatures had a negative effect on meat quality parameters and the incidence of DFD and PSE meat, respectively. Accordingly, the pigs slaughtered in winter and summer produced the lowest meat quality. Hence, farmers and pork producers should protect pigs from extreme ambient conditions with appropriate bedding and ventilation in winter and by showering during lairaging in summer.

\section{Acknowledgements}

This paper was supported by Ministry of Education, Science and Technological development, Republic of Serbia, Project "Selected biological hazards to the safety/quality of food of animal origin and the control measures from farm to consumer" (No. 31034).

\section{Authors' Contribution}

NK defined the research theme and gave the conception of the research. NK, NČ, MB, JDj and MD carried out experimental part of the study. NK, NČ and NP have made substantial contributions to conception and design, or acquisition of data, or analysis and interpretation of data. NK and DV have been involved in drafting the manuscript or revising it critically for important intellectual content. All authors have read and approved the final manuscript.

\section{Conflict of Interest Declaration}

There are no conflicts of interest.

\section{References}

Adzitey, F., 2011. Effect of pre-slaughter animal handling on carcass and meat quality. Int. Food. Res. J. 18, 2, 485-491.

Adzitey, F. \& Nurul, H., 2011. Pale soft exudative (PSE) and dark firm dry (DFD) meats: Causes and measures to reduce these incidences. Int. Food. Res. J. 18, 11-20.

Alonso, V., del Mar Campo, M., Español, S., Roncalés, P., Beltrán, J.A., 2009. Effect of crossbreeding and gender on meat quality and fatty acid composition in pork. Meat Sci. 81, 209-217.

Anon., 1985. Pravilnik o kvalitetu zaklanih svinja i kategorizaciji svinjskog mesa (Official Gazette SFRJ, No 2/85, 12/85, 24/86) (in Serbian).

Barton-Gade, P., Christensen, L., 1998. Effect of different stocking densities during transport on welfare and meat quality in Danish slaughter pigs. Meat Sci. 48, 3/4, 237-247.

Bridi, A.M., Oliveira, A.R., Fonseca, N.A.N., Shimokomaki, M., Coutinho, L.L., Silva C.A., 2006. Effect of halothane genotype, ractopamine and sex on pork meat quality. Rev. Bras. Zootec. 35, 5, 2027-2033 (in Portuguese, English abstract).

Choe, J.H., Choi, M.H., Ryu, Y.C., Lim, K.S., Lee, E.A., Kang, J.H., Lee, K.W., 2015. Correlations among various blood parameters at exsanguination and their relationships to pork quality traits. Anim. Prod. Sci. 55, 5, 672-679.

Chulayo, A.Y. \& Muchenje V., 2015. A balanced perspective on animal welfare for improved meat and meat products. S. Afr. J. Anim. Sci. 45, 5, 452-469.

Cisneros, F., M. Ellis, McKeith, F.K., McCaw, J., Fernando R.L., 1996. Influence of slaughter weight on growth and carcass characteristics, commercial cutting and curing yields, and meat quality of barrows and gilts from two genotypes. J. Anim. Sci. 74, 925-933.

Čobanović, N., Karabasil, N., Stajković, S., Ilić, N., Suvajdžić, B., Petrović, M., Teodorović, V., 2016, The influence of pre-mortem conditions on pale, soft and exudative (PSE) and dark, firm and dry (DFD) pork meat, Acta VetBeograd 66, 2, 172-186. 
Correa, J.A., Faucitano, L., Laforest, J.P., Rivest, J., Marcoux, M., Garièpy C., 2006. Effects of slaughter weight on carcass composition and meat quality in pigs of two different growth rates. Meat Sci. 72, 91-99.

Correa, J.A., Gonyou, H.W., Torrey, S., Widowski, T., Bergeron, R., Crowe, T.G., Laforest, J.P., Faucitano, L, 2013. Welfare and carcass and meat quality of pigs being transported for 2 hours using two vehicle types during two seasons of the year. Can. J. Anim. Sci. 93, 43-55.

Czyżak-Runowska, G., Wojtczak, J., Łyczyński, A., Wójtowski, J., Markiewicz-Kęszycka, M., Stanisławski, D., Babicz, M., 2015. Meat quality of crossbred porkers without the gene $R Y R 1^{\top}$ Depending on slaughter weight. Asian Australas. J. Anim. Sci. 28, 3, 398-404.

Dalla Costa, F.A., Devillers, N., da Costa, M. P., \& Faucitano, L., 2016. Effects of applying pre-slaughter feed withdrawal at the abattoir on behaviour, blood parameters and meat quality in pigs. Meat Sci. 119, 89-94.

Dalla Costa, O.A., Faucitano, L., Coldebella, A., Ludke, J.V., Peloso, J.V., DallaRoza, D., Paranhos da Costa, M.J.R., 2007. Effects of the season of the year, truck type and location on truck on skin bruises and meat quality in pigs. Livest. Sci. 107, 29-36.

European Commission, 2005. Council Regulation n.1/2005 on the Protection of Animals during Transport and Related Operations and Amending Directives 64/432/EEC and 93/119/EC and Regulation (EC) No 1255/97. Official Journal of the European Union, L3, 22/12/2004, 1-44.

Faucitano, L., 2010. Invited review: Effects of lairage and slaughter conditions on animal welfare and pork quality. Can. J. Anim. Sci. 90, 461-469.

Fox, J., Widowski, T., Torrey, S., Nannoni, E., Bergeron, R., Gonyou, H. W., Faucitano, L., 2014. Water sprinkling market pigs in a stationary trailer. 1. Effects on pig behaviour, gastrointestinal tract temperature and trailer micro-climate. Livest. Sci. 160, 113-123.

Franco, M.M., Antunes, R.C., Borges, M., Melo, E.O., Goulart, L.R., 2008. Influence of breed, sex and growth hormone and halothane genotypes on carcass composition and meat quality traits in pigs. J. Muscle. Foods 19, 34-49.

Gajana, C.S., Nkukwana, T.T., Marume, U., Muchenje, V., 2013. Effects of transportation time, distance, stocking density, temperature and lairage time on incidences of pale soft exudative (PSE) and the physico-chemical characteristics of pork. Meat Sci. 95, 520-525.

Gispert, M., Angels Oliver, M., Velarde, A., Suarez, P., Pérez, J., Font i Furnols, M., 2010. Carcass and meat quality characteristics of immunocastrated male, surgically castrated male, entire male and female pigs. Meat Sci. 85, 664-670.

Gosálvez, L.F., Averós, X., Valdevira, J.J., Herranz, A., 2006. Influence of season, distance and mixed loads on the physical and carcass integrity of pigs transported to slaughter. Meat Sci. 73, 553-558.

Goumon, S., Brown, J. A., Faucitano, L., Bergeron, R., Widowski, T. M., Crowe, T., Gonyou, H. W., 2013. Effects of transport duration on maintenance behaviour, heart rate and gastrointestinal tract temperature of market-weight pigs in 2 seasons. J. Anim. Sci. 91, 4925-4935.

Grandin, T., 2003. The welfare of pigs during transport and slaughter. Pig News and Information 24, 83-90.

Guàrdia, M.D., Estany, J., Balasch, S., Oliver, M.A., Gispert, M., Diestre, A., 2004. Risk assessment of PSE condition due to pre-slaughter conditions and RYR1 gene in pigs. Meat Sci. 67, 471-478.

Guàrdia, M.D., Estany, J., Balasch, S., Oliver, M.A., Gispert, M., Diestre, A., 2005. Risk assessment of DFD meat due to pre-slaughter conditions in pigs. Meat Sci. 70, 709-716.

Guàrdia, M.D., Estany, J., Balasch, S., Oliver, M.A., Gispert, M., Diestre, A., 2009. Risk assessment of skin damage due to pre-slaughter conditions and RYR1 gene in pigs. Meat Sci. 81, 745-751.

Guise, H.J., Riches, H.L., Hunter, E.J., Jones, T.A, Warriss, P.D., Kettlewell, P.J., 1998. The effect of stocking density in transit on the carcass quality and welfare of slaughter pigs: 1 . Carcass measurements. Meat Sci. 50, 4, 439-446.

Hale, O.M., 1971. Supplemental fat for growing-finishing swine.Feedstuffs 43, 16.

Hugo, A. \& Roodt, E., 2015. Fat quality of South African pigs with different carcass classification characteristics. S. Afr. J. Anim. Sci. 45, 3, 302-312.

SPSS, 2015. Statistical Package for Social Sciences for Windows (version S23.0). SPSS Inc., Armonk, NY: IBM Corp., USA.

Jama, N., Maphosa, V., Hoffman, L.C., Muchenje, V., 2016. Effect of sex and time to slaughter (transportation and lairage duration) on the levels of cortisol, creatine kinase and subsequent relationship with pork quality. Meat Sci. $116,43-49$.

Jaturasitha, S., Kamopas, S., Suppadit, T., Khiaosaard, R., Kreuzer M., 2006. The effect of gender of finishing pigs slaughtered at 110 kilograms on performance, and carcass and meat quality. Science Asia 32, 297-305.

Karabasil, N., Dokmanović, M., Dimitrijević, M., Teodorović, V., Kojičić-Stefanović, J., Glamočlija, N., Baltić, Ž.M., 2013a. Assessment of welfare conditions during stunning of pigs with respect to the day of the week. Tehnologija mesa 54, 2, 89-96 (in Serbian, English abstract).

Karabasil, N., Vasiljević, M., Dimitrijević, M., Vučinić, M., Đorđević, V., Ivanović, J., Kureljušić, J., 2013b. The study of transport conditions of pigs to the slaughterhouse. Tehnologija mesa, 54, 1, 1-7 (in Serbian, English abstract).

Lambertini, L., Vignola, G., Badiani, A., Zaghini, G., Formigoni, A., 2006. The effect of journey time and stocking density during transport on carcass and meat quality in rabbits. Meat Sci. 72,4, 641-646.

Latorre, M.A., Medel, P., Fuentetaja, A., Lazaro, R., Mateos, G.G., 2003. Effect of gender, terminal sire line and age at slaughter on performance, carcass and meat quality of heavy pigs. Anim. Sci. 77, 33-45.

Latorre, M.A., Lazaro, R., Valencia, D.G, Medel, P., Mateos, G.G, 2004. The effects of gender and slaughter weight on the growth performance, carcass traits, and meat quality characteristics of heavy pigs. J. Anim. Sci. 82, 526-533.

Latorre, M. A., García-Belenguer, E., Ariño, L., 2008. The effects of sex and slaughter weight on growth performance and carcass traits of pigs intended for dry-cured ham from Teruel (Spain). J. Anim. Sci. 86, 1933-1942. 
Łyczyński, A., Wajda, S., Czyżak-Runowska, G., Rzosińska, E., Grześ, B., 2006. Effect on environmental condition on pork meat quality. Pol. J. Food Nutr. Sci. 15/56, 109-116.

Myer, R. \& Bucklin, R.A., 2007. Influence of rearing environment and season on growth performance of growing-finishing pigs. T. ASABE 50, 2, 615-620.

Nanni Costa, L., Lo Fiego, D.P., de Grossi, I.A., Russo, V., 2002. Combined effects of pre-slaughter treatments and lairage time on carcass and meat quality in pigs of different halothane genotype. Meat Sci. 61, 41-47.

Nannoni, E., Widowski, T., Torrey, S., Fox, J., Rocha, L. M., Gonyou, H., Faucitano, L., 2014. Water sprinkling market pigs in a stationary trailer. 2. Effects on selected exsanguination blood parameters and carcass and meat quality variation. Livest. Sci. 160, 113-123.

National Pork Board, 2008. Transport quality assurance handbook.

Olessen, L.S., Nygaard, C.M., Friend, T.H., Bushong, D., Knabe, D., Vestergaard, K.S., Vaughan, R.K., 1996. Effect of partitioning pigs on aggressive behavior of pigs regrouped at weaning. Appl. Anim. Behav. Sci. 46, 167-174.

Oliveira, E.A., Bertol, T.M., Coldebela, A., Santos Filho, J.I., Scandolera, A.J., Warpechowski, M.B., 2015. Live performance, carcass quality, and economic assessment of over $100 \mathrm{~kg}$ slaughtered pigs. Arq. Bras. Med. Vet. Zootec. 67, 6, 1743-1750.

Pereira, T.L., Corassa, A., Komiyama, C.M., Araújo, C.V., Kataoka, A., 2015. The effect of transport density and gender on stress indicators and carcass and meat quality in pigs. Span. J. Agric. Res., 13, 3, 1-11.

Perez, M.P., Palacio, J., Santolaria, M.P., del Acena, M.C., Chacon, G., Verde, M.T., Calvo, J.H., Zaragoza, M.P.,Gascon, M.,Garcia-Belenguer, S., 2002. Influence of lairage time on some welfare and meat quality parameters in pigs. Vet. Res. 33, 239-250.

Pineiro, C., Lorenzo, E., Pineiro, A., Mateos, G.G., 2001. Effects of induced stresses on productive performance and serum concentration of acute phase proteins in growing-finishing pigs. J. Anim. Sci., 79, 1, 211.

Piwczyński, D., Wochna, P., Kolenda, M., Czajkowska, A., 2013. The effect of slaughtering season on the carcass quality of growing finishing pigs. Pol. J. Natur. Sc. 28, 4, 437-448.

Scheeren, M. B., Gonyou, H. W., Brown, J., Weschenfelder, A. V., \& Faucitano, L., 2014. Effects of transport time and location within truck on skin bruises and meat quality of market weight pigs in two seasons. Can. J. Anim. Sci. 94, 1, 71-78.

Turner, S.P., Farnworth, M.J., White, I.M.S., Brotherstone, S., Mendl, M., Knap, P., Penny, P., Lawrence, A.B., 2006. The accumulation of skin lesions and their use as a predictor of individual aggressiveness in pigs. Appl. Anim. Behav. Sci. 96, 245-259.

Vermeulen, L.,, Van de Perre, V., Permentier, L., De Bie, S., Geers, R., 2015. Pre-slaughter handling and pork quality. Meat Sci. 100, 118-123.

Warriss, P.D., Brown, S.N., Edwards, J.E., Knowles, T.G., 1998. Effect of lairage time on levels of stress and meat quality in pigs. Anim. Sci. 66, 255-261.

Welfare Quality®.Welfare Quality® Assessment Protocol for Pigs (sow and piglets, growing and finishing pigs). Welfare Quality® Consortium 2009, Lelystad, The Netherlands.

Zhen, S., Liu, Y., Li, X., Ge, K., Chen, H., Li, C., Ren, Fazheng., 2013. Effects of lairage time on welfare indicators, energy metabolism and meat quality of pigs in Beijing. Meat Sci. 93, 287-291. 